Mention must also be made of the considerable experimental and engineering work involved in the equipment of the London Television Station at Alexandra Palace towards the end of the year under review. The report concludes with a summary of the financial position of the Corporation as at December $31,1936$.

\section{The Need for Motor-car Inspection}

REvised regulations for the construction and use of motor vehicles in Great Britain have just been issued by the Ministry of Transport. They provide, among other matters, for the testing of brakes, steering gear, etc., of a vehicle on the road. In about a dozen of the States forming the U.S.A., it is compulsory for motorists to have their cars inspected to see that they comply with safety regulations. According to a recent note issued by Science Service, of Washington, D.C., it is an even chance whether the motorist will find that his car falls below the requirements for safety on the road or not. The most common fault is bad brakes, but it is not unusual to find that lights are out of focus and wheels out of alignment. In some cases, the owner finds that it would cost him more than his car is worth to make the repairs and so it is relegated to the scrap heap, an action which may possibly have saved the lives of other people as well as his own. Last year in Pennsylvania alone, nearly 15,000 of the vehicles were found to be decrepit, and quietly passed out of circulation. Whenever inspection laws are passed in a State, it has been noticed that there is a great decrease in the number of 'collegiate' models which run on the roads on four wheels with no brakes. It is impossible to say what percentage of highway accidents can be attributed to mechanical defects of the cars, as after a wreck there is little left to test. It is reasonable to conclude that when about half the cars in a State have faulty brakes, they are to blame for some of the tragedies which occur. Because cars are fitted with good tyres and good brakes initially, we are apt to forget that the average car on the road is nearly five years old and is generally slightly shaky. Railway trains and air liners, operated by experts, have to pass a rigid inspection to see whether they are safe. Motor-car drivers are usually amateur mechanics; it is rash to assume that their equipment is safe.

\section{Education in Canada}

CANADIAN education, as seen in the course of a four-months winter visit, was the theme of a paper read by Dr. F. H. Spencer, late chief inspector, Education Department, London County Council, before the Royal Society of Arts on November 11 last, and recently made available in print. Although the purpose of the visit was to lecture on English, not to investigate Canadian education, and Dr. Spencer disclaims any title to be listened to as an authority on this subject, his comparisons of school buildings, organization, teacher-training and university extension work in Canada and in England are enlightening, even though admittedly superficial. The most satisfactory of his impressions was of the prevalent enthusiasm for popular education, and the most unsatisfactory was of excessive regimentation alike in the primary and in the secondary schools. He was struck by the importance of the service rendered by the universities through their extension departments, and especially their correspondence courses, to remote but interested and ambitious students in the backwoods. The travels of the university extension tutors in the winter into such remote regions provide them with a stimulating adventure-an experience to which a counterpart has sometimes been found in Great Britain, for remoteness is not always to be measured in miles. In the course of the discussion following the reading of the paper, Prof. Krug of Mt. Allison, New Brunswick, observed that there have been few more worthy contributions to Canadian education and to Empire unity than the visit paid to Canada last year by a group of British school administrators and inspectors; a visit which made, he said, a really deop impression.

\section{Physiology and Hygiene in Education}

THE place of physiology and hygiene in general education has yet to be effectively established. Intellectual assent has been generally accorded to Herbert Spencer's dictum-that such a course of physiology as is needful for the comprehension of its general truths, and their bearings on daily conduct, is an all-essential part of a rational education--but those responsible for curricula have not so generally given practical effect to such assent. The subject has lately been investigated by Dr. J. P. Rogers for the United States Office of Education. In his report on "Instruction in Hygiene in Institutions of Higher Education" (Washington, D.C. : Government Printing Office. 10 cents), he observes that only a third of the colleges and universities require attendance at a course in hygiene by their students, and it is rare that any instruction concerning the human body is furnished in the last three years of secondary school work. He quotes some interesting criticisms by university authorities of the methods of instruction in use : one president remarks "my observation has been that this course has been too technical and not sufficiently practical. I have yet to find an instructor who can put the information in a practical way". It takes an artist, says Dr. Rogers, to fill such a requirement, and the best teacher of hygiene is the master and not the servant of that body of tradition which passes for 'science' in his day.

\section{Extension of Scientific Buildings in Oxford}

A FORECAST of extensions of scientific departments in Oxford is contributed by Dr. A. S. Russell, of Christ Church, to the spring number of Oxford, the journal of the Oxford Society. Within three or four years, a new physics laboratory for Prof. F. A. Lindemann will, it is hoped, be put up in the Parks, when the Clarendon Laboratory, now occupied by him, could be adapted to the uses of the Department of Geology now inadequately housed in the Museum. These improvements are expected to be closely 